\title{
Circular Economy in Mineral Processing
}

\author{
Radostaw Pomykała ${ }^{1}$, and Barbara Tora ${ }^{1, *}$ \\ ${ }^{1}$ AGH University of Science and Technology, Faculty of Mining and Geoengineering, Kraków, Poland
}

\begin{abstract}
The paper aims to implementation of Circular Economy in mineral processing in Poland. Circular economy represents a completely new approach to product life cycle, based on the departure from the linear model of "take - make - dispose" and turning to the circular or closed-circle model of economy. Challenges and opportunities of implementation of Circular Economy in Mining is presented. The VERAM project, financed by The European Union (by the EUR 1.4 million) to the project is described. The examples of good practice in the area of implementation of circular economy in Poland is presented (Tauron Wydobycie - wasteless mine and ZGH Bolesław - waste management)
\end{abstract}

\section{Introduction}

The European Commission accepted a package of documents concerning Circular Economy on 2 December 2015. Circular economy represents a completely new approach to product life cycle, based on the departure from the linear model of "take - make - dispose" and turning to the circular or closed-circle model of economy. Increase of such activities as recycling and reuse of products brings benefits not only to the environment but also to economy, e.g. in the form of raw-material savings or reduced waste quantities.

First international conference on minerals in Circular Economy was organized by VTT Technical Research Centre of Finland, GTK Geological Survey of Finland, Aalto University, University of Oulu on 26-27 November 2014.

The modern society is based on using mineral commodities: their total consumption correlates with economic growth and urbanization. Due to population growth on the global level, the total consumption of mineral raw materials is expected to increase. At the same time, the transition towards a circular economy plays a key role in decreasing per capita consumption of minerals. For this transition to happen, top class scientific research that allows for knowledge transfer between different segments of the mineral value chain is required. Sustainable mining, enhanced material recovery, better material and product design, and sustainable resource policies are all essential parts of the science to meet the demands of the circular economy. They are also closely supported by the European Innovation Partnership (EIP) on Raw Materials and the upcoming Knowledge and Innovation Community (KIC) on raw materials, which aim to improve the mineral sector's possibilities for sustainable growth, creating more jobs in Europe and securing the European industries' raw material needs. The Ellen MacArthur Foundation sees its mission as accelerating the transition from a linear take-make- dispose economic model to a circular model that is restorative and regenerative by design and aims to keep products, components and materials at their highest utility and value at all times. Furthermore, the European Commission has adopted a Circular Economy Package, including revised legislative proposals on waste, to stimulate Europe's transition towards a circular economy to boost global competitiveness, foster sustainable economic growth and generate new jobs.

\section{Mc Kinsey report}

A new McKinsey analysis on the benefits of circular economy was prepared in 2015.

The McKinsey Global Institute drafted the Report_on circular economy, or the economy which emphasizes specific, super-effective treatment of raw materials and materials that does not interfere with natural balance (only biological materials are returned to nature). The so-called second-generation recycling may bring 1,8 billion euros in economic benefits [European billion], in addition to environmental and social advantages, until 2030. Europe depends on raw materials to a large extent and that also creates considerable possibilities of efficient material reuse improvement which will give impetus to better resource productivity and competitiveness.

Europe is wasteful in the area of raw-material consumption which is demonstrated by the "take - make - dispose" model. In 2012, the average European used 16 metric tons of various types of materials, with only 40 percent recycled or reused. That kind of wastefulness is also visible e.g. in the use of cars (European cars remain parked 92 percent of the time, without transporting people), or food (31 percent of food is wasted during processing), or office operation (only 35 to 50 percent of the time is used properly). And there are more surprising and original observations of that kind.

\footnotetext{
* Corresponding author: tora@agh.edu.pl
} 
The European Commission approved a new ambitious package of documents concerning circular economy. The new approach should assist European companies and consumers in switching to circular economy in which resources are used in a more sustainable manner.

Proposed actions would contribute to "closing the circle" of product lifetime owing to increased recycling and reuse, bringing advantages to both the environment and economy. Implementation of the related plans will allow to maximise value, utmost use of all raw materials, products and waste, with the intention to save energy and reduce green-house gas emissions.

Specific proposals entail the whole product life cycle: from manufacturing to consumption to waste management to recycled materials market. That process will be financially supported by the European structural and capital-investment funds of which 5.5 billion euros will be designated for capital investments in the area of waste management. Additional support of 650 million euros will be made available by the EU under the "Horizon 2020" Programme for research and innovation, as well as capital investments in circular economy at the national level.

\section{Closing the loop - An EU action plan for the Circular Economy}

The European Commission adopted an ambitious Circular Economy Package, which includes revised legislative proposals on waste to stimulate Europe's transition towards a circular economy which will boost global competitiveness, foster sustainable economic growth and generate new jobs.

The Circular Economy Package [3] consists of an $\underline{\mathrm{EU}}$ Action Plan for the Circular Economy that establishes a concrete and ambitious programme of action, with measures covering the whole cycle: from production and consumption to waste management and the market for secondary raw materials. The annex to the action plan sets out the timeline when the actions will be completed.

The proposed actions will contribute to "closing the loop" of product lifecycles through greater recycling and re-use, and bring benefits for both the environment and the economy.

The revised legislative proposals on waste set clear targets for reduction of waste and establish an ambitious and credible long-term path for waste management and recycling.

Key elements of the revised waste proposal include:

- A common EU target for recycling $65 \%$ of municipal waste by 2030 ;

- A common EU target for recycling $75 \%$ of packaging waste by 2030 ;

- A binding landfill target to reduce landfill to maximum of $10 \%$ of municipal waste by 2030 ;

- A ban on landfilling of separately collected waste;

- Promotion of economic instruments to discourage landfilling ;

- Simplified and improved definitions and harmonised calculation methods for recycling rates throughout the $\mathrm{EU}$;
- Concrete measures to promote re-use and stimulate industrial symbiosis - turning one industry's by-product into another industry's raw material;

- Economic incentives for producers to put greener products on the market and support recovery and recycling schemes (eg for packaging, batteries, electric and electronic equipments, vehicles).

\section{Environmental Protection and Efficient Resource Management}

The EU cohesion policy supports sustainable development by promoting water and waste management, environmentally friendly and innovative pure technologies, as well as the activities intended to protect air, biodiversity, and nature.

The EU structural and capital-investment funds help to protect and preserve such natural resources as water, nature, biodiversity, clean air, and raw materials. Those funds are spent for capital investments in infrastructure designed for liquid waste treatment and solid waste management (e.g. recycling), as well as all necessary means for environmental monitoring systems and green infrastructure development. Owing to such activities, our environment becomes a source of economic growth and new possibilities for creating jobs.

\section{Objectives}

- To stimulate Europe's switching to circular economy and increase global competitiveness

- To support sustainable economic development

- To create new jobs

- To increase product lifetime through circular economy, e.g. by the following:

- design allowing for easy repair, reuse, or processing,

- durability improvement,

- promotion of damaged equipment repairs instead of replacement,

- better waste management,

- new business and consumption models based on product sharing, borrowing, exchanging, or leasing .

\section{Goal: To close the materials circulation}

Through the following:

- Limitation of raw-material consumption

- Optimisation of the production processes

- Reduction of energy consumption

- Prolongation of product life cycles

- Maximisation of waste recycling and recovery

- Limitation of environmental impact (environmental trace). 


\section{Circular Economy: Areas of Action}

1. Product design stage

2. Distribution

3. Use or consumption

4. Public procurement

5. Product labelling and product information

6. Waste management

7. Development of recovered materials market

8. Improvement of conditions in such priority sectors as:

a) sustainable production

b) recycled material recovery

c) building industry

d) critical raw materials

9. Improvement of intersectoral collaboration, e.g. by the promotion of industrial symbiosis, repairs and reuse, as well as

10. Development of new business models

\subsection{Circular Economy}

- Limitation of the quantity of materials required for the provision of a specific service

- Prolongation of the product availability (durability)

- Limitation of the consumption of energy and materials at the stages of manufacturing and use (effectiveness)

- Limitation of the use of hazardous or hard-to-recycle materials in products and production processes (substitution)

- Development of the recycled materials (recyclate) market, based on standards, public procurement etc.

- Designing the products that are easy to maintain, repair, modernise, remodel, or recycle (ecodesigns)

- Development of necessary services for the consumers in a given area (maintenance, repairs etc.)

- Encouraging the consumers to limit waste and implement high quality waste segregation, with offering support in those areas

- Encouraging the consumers to segregate waste and apply waste collection systems to minimise recycling and reuse;

- Facilitation of activities intended to prevent discarding side products as waste (industrial symbiosis)

- Stimulation of the conditions that facilitate wider and better consumer choices by relying on lease services

- Product renting and sharing as an alternative to product owning, with concurrent consumer interest protection (in respect of costs, safety, information, contractual conditions, insurance aspects etc.)

\section{Circular Economy Implementation}

During the workshop meetings conducted at this year's Green Week in Brussels (3-5 June 2017), a number of new solutions and possibilities, identified on the basis of the experiences drawn from successful initiatives, were presented. Those can be applied on a larger and broader scale involving:

- At the production stage: environmentally balanced standards of supplier selection, voluntary systems applied in industrial branches and among retail sellers, as well as industrial symbiosis for better use of raw materials and waste control, with the creation of sideproduct markets,

- At the distribution stage: better information on the resources contained in products and the methods of product repair or recycling, known as "product passports",

- At the consumption stage: shared consumption models, based on product borrowing, swap, replacement, and lease (e.g. lease of home appliances), and product-and-service systems designed to obtain higher value from inadequately used assets or resources (e.g. cars, tools, or premises).

\section{Key Elements of Building Circular Economy in Poland}

1. Innovation, increased co-operation between industrial and scientific sectors, leading to the implementation of innovative solutions in economy.

2. Creation of the European recycled materials market, with facilitated materials flows.

3. Ensuring high quality recycled materials, resulting from sustainable production and consumption,

4. Development of the services sector.

\subsection{The Areas of Mining Activities in Circular Economy}

- $\quad$ Feeding and supplementing raw-material cycles

- Dedicated products causing low emissions

- Responsibility for product quality

- Optimisation of own production cycles

- Increase of production efficiency, including:

- Reduction of raw-materials waste

- Use of methane

- Limitation of energy consumption

- Limitation of the effect of mining on the environment

- Optimisation of waste management

- $\quad$ Towards waste-free mining

- Intersectoral collaboration

- Development of services assisting mining operations

- Facilitation of closing cycles in other sectors, including power generation

\subsection{Indicators Designed for the Waste-Free Coal Power Generation Model}

To evaluate the efficiency of the implementation of circular economy, certain indicators have been proposed [2].

\subsection{Waste rate indicator, Wo}

The indicator determines the quantity of waste generated per base product unit. In the case of energy generation, electricity and thermal energy will be the base units. The indicator will tell us to what extent production is clean and 
what are the possibilities of reducing waste in a given plant.

$$
\mathrm{Wo}=\mathrm{O} / \mathrm{P}
$$

$\mathrm{O}$ - waste; $\mathrm{P}$ - products

Units, e.g.: ton/MWe (metric ton per megawatt of electric power), ton/MWt (metric ton per megawatt of thermal power) etc.

The objective of waste-free coal power generation is to obtain the Wo indicator equal zero.

\subsection{Productivity indicator, Wp}

The indicator determines the proportion between the generated waste and the waste processed into raw materials and products.

$$
\mathrm{Wp}=\mathrm{S}+\mathrm{P} / \mathrm{O}
$$

$\mathrm{S}+\mathrm{P}$ - raw materials and products generated by man and sold

$\mathrm{O}$ - waste

Unit: dimensionless indicator, ton/ton

The objective of waste-free coal power generation is to obtain the $\mathrm{Wp}$ indicator equal one.

\section{Implementation of Circular Economy: Challenges and Opportunities in Mining}

- Possibilities of obtaining financial resources for innovative projects

- Integration of pro-environmental activities

- Development of product-oriented approach to waste management

- Analysis of the environmental trace (including that in respect of other energy generation technologies)

- Improvement of the image of the mining sector

- Finding additional reasons in the efforts to maintain the share of coal in the energy generation mix

\subsection{Implementation of the Circular Economy Principle in the Polish Mining Sector}

During the International Mining Forum held in Jastrzębie Zdrój in June 2017, Mr. Tadeusz Koperski, the President of Kopex, presented a conception of organising a system of implementing circular economy in the mining sector [4].

There is a need to select the operator whose general mission will be to associate the operating system, based on the circular economy paradigm, with a broadly understood waste management business model. The necessity to integrate those two systems results from the limitation of current directions of waste management or even their eradication.

A systemic approach will allow us to optimise the structures facilitating waste management, as well as expenditures for current operations, acquire new markets, and support and develop innovations for both operator's structures and co-operating stakeholders.
Organisational innovation will allow us to create a recycled and circular-economy materials market, based on a business action model [4].

Some examples of good practice in the implementation of circular economy in Poland were presented at the International Mining Forum: "Implementation of the Waste-Free Coal Mine Policy in the Tauron Wydobycie Company", "Waste Management in the ZGH Bolesław" [5].

\subsection{The Cohesion Policy}

Cohesion policy investments are geared towards local needs and opportunities. They contribute to $[6,7]$ :

- more recycling,

- improved waste management,

- resource and energy efficiency,

- strengthening the bio-economy,

- novel solutions in product design,

- new business models,

- $\quad$ and the creation of green jobs.

For improved waste management, EU has $€ 5.5$ billion focusing on waste prevention, reuse and recycling. EU also invests in basic waste treatment infrastructure in less developed regions. This means 5.9 million tonnes/year of additional waste recycling capacity in Europe.For SMEs, EU invests EUR 2.3 billion in environmentally-friendly production processes and resource efficiency. This helps them save costs and creates new opportunities by turning waste into a resource.

Important research and innovation funding opportunities are available too, for instance to develop new and better products. Regions from all Member States identified priorities related to circular economy in their Smart Specialisation Strategies. The Smart Specialisation Platform helps these regions to cooperate with others along value chains, also on specific topics such as industrial modernisation, agri-food and energy.

The Circular Economy Package also promotes water reuse. Several regions in the EU already recycle their treated wastewater for park irrigation, street cleaning or to replenish groundwater reserves.

Cohesion policy can support this further, through its $€ 15$ billion investment in the water sector during the 2014-2020 period.

\section{VERAM Project}

The recently launched VERAM [1,9] project will deliver a long-term 2050 Vision and Roadmap for European Raw Materials. The European Union (EU) has awarded 1.4 million to the project under Horizon 2020 programme.

Patrick Wall, project coordinator, has given more details on this coordination and support action on raw materials project, and on how a long-term vision and roadmap will be developed. [veram2050.eu]

Europe's dependence on other continents for raw materials is enough of a concern to be included among the topics that form the third pillar of Horizon 2020, Societal Challenges. One call under this pillar sought applications for a coordination and support action (CSA) to improve 
the coordination of raw materials research and innovation activities between the EU and member states, and to develop a long-term vision for the field.

The VERAM project is being coordinated by the European Technology Platform on Sustainable Mineral Resources. Platform is industry-led member organization and has an important role in driving innovation. The area covered energy, environment, ITC, production and processes, transport, and the bioeconomy, which is based on biotechnology research.

VERAM's Work Plan includes the identification of the current status and a gap analysis, the development of a long-term vision and a roadmap, and the dissemination of the vision and roadmap for 2030 and 2050.

The VERAM project will produce a Vision and Roadmap for European Raw Materials in 2050 based on raw materials research and innovation (R\&I) coordination.

Two leading European Technology Platforms (ETPs): ETP SMR (Sustainable Minerals Resources) and FTP (Forest Technology Platform) are joining forces to develop a common vision and roadmap with the support of ECTP (European Construction Technology Platform), represented by UNIVPM, SusChem(ETP for Sustainable Chemistry), represented by Cefic, and EuMaT (Advanced Materials ETP), represented by VITO. This partnership provides VERAM with expertise from downstream applications and additional knowledge on secondary raw materials.

\section{Conclusions - good practices in Polish mineral processing}

The examples of good practice in the implementation of circular economy in Poland were presented at the International Mining Forum.

An example of good solutions in the implementation of circurlar economy are summarized below.

\subsection{Wasteless mine - case TAURON Wydobycie}

Tauron Mining S.A. is the producer of coal - the part of TAURON Mining are three mining plants: Sobieski and Jaworzno and Brzeszcze. These plants are seen as the moder ones. They are producting about 8 million tones/year of coal, simultaneously, apart from they are producing also about $2 \mathrm{mln}$ tonnes/year of rock and additional materials $[11,12]$.

In the following years, the proecologic activities of TAURON Mining S.A. will focus around using the potential of partnerships of the Group TAURON to work out the model of management of produced "wastes", mainly inside of the Group. In this purpose, the project Grey2Green was initiated between areas of energetic partnerships and TAURON Mining S.A., which idea is based on using the effect of synergy in the direction of wastes management. The realization of the project's assumptions is based also on applying innovative technologies in the planned investments of constructing special installments dedicated to pro- cess of various sorts of "wastes" and transform them into products. Thanks to greener investments, realized in TAURON Mining S.A. it was possible to manage or process both own wastes as well these originating from TAURON Wytwarzanie S.A. Additionally, the planned investments as modernization of installments to direct the slimy-ash suspension in ZG Sobieski to the bottom of the mines in purpose of fire prevention as well implementation of innovative technology of complex "cleaning" of slime tanks will allow to manage totally the coal slimes. This concerns both slimes being produced directly as well these ones which are still stored in tanks what will bring back their func- tionality.

\subsection{Waste management in ZGH Bolesław}

ZGH „Bolesław” S.A. (Mining and Metallurgical Plant Bolesław) is a producer of Special High Grade Zinc and its products. ZGH "Bolesław" S.A. extract and process zinc and lead ores coming from his own mine, produce electrolytic zinc, zinc alloys, sulphuric acid and zinc and lead concentrates. ZGH Bolesław produce zinc using electrolysis process and imperial smelting process as well as we recycle zinc waste materials in the Waelz process. The technologies he use protect the environment $[8,9$, $10]$.

ZGH Boleslaw SA continues the current directions of applying wastes which are significantly related to environmental protection

- Construction of levees of active pond from coarser fractions of tailings gives additional capacity for disposal being equal to volume of residues built into levees. It elongates also the time of exploitation of current ponds without the necessity of gaining additional areas for location of new ones.

- The application of tailings to construct levees and as a component of hydraulic backfill eliminates the necessity of opening sand mines causing degradation of forests and fields.

- Application of tailings within last years as reclamation material allowed to perform such action for objects hard to proceed with and to restore landscape virtues for areas degraded by mining activity.

- The application of flotation tailings is connected with necessity of their wet, periodical storage in ponds till their drying. For now, lack of technical possibilities and real new directions for total and fast application of all wastes being created excludes the possibility of liquidation of the ponds.

\section{References}

1. H. Karaś: Is the 4th Industrial Revolution in the EU Industry a chance for the RM sector. Veram Stakeholder Forum (Antverp, Belgium, 2016)

2. T. Szczygielski (red): Mineraty antropogeniczne a gospodarka o obiegu zamknietym (Politechnika Warszawaska, Instytut Badan Stosowanych, Warszawa, 2015) 
3. Report from the commission to the european parliment on the implementation of the Circular Economy Action Plan, Annex 1, (Brussels, COM 33, 2017)

4. T. Koperski, Innowacje organizacyjne jako podstawa do systemowego wdrażania rozwiązań gospodarki opartej na zasadzie gospodarki odpadowej w obiegu zamkniętym $\mathrm{z}$ wykorzystaniem technologii innowacyjnych, Interantional Mining Forum (Jastrzębie Zdrój, 2017)

5. R. Pomykała, B. Tora: Rola Górnictwa w gospodarce o obiegu zamkniętym, Interantional Mining Forum (Jastrzębie Zdrój, 2017)

6. www.mos.gov.pl, Plan działań dla Zamknięcie obiegu" dokument identyfikujący główne priorytety Polski w zakresie GOZ (2015)

7. https://www.ausimmbulletin.com/feature/thecontribution-of-mining-to-the-emerging-circulareconomy/
8. http://veram2050.eu

9. R. Tomanec, M. Blagojev, J. Pol. Miner. Eng. Soc. , 1(39), 165-172 (2017)

10. A. Jarosiński, S. Żelazny, M. Cholewa, Pol. Miner. Eng. Soc., 1(37), 233-240 (2016)

11. Z. Śmieszek, K. Cichy, A. Wieniewski, B.Ochab, C.Regula: Odpady flotacyjne jako potencjalne ródło zasobów surowcowych na przykładzie rud $\mathrm{Zn}-\mathrm{Pb}$, Konferencja IMN, (Gliwice, 2011)

12. A. Nowak, A. Pawluk, Pol. Miner. Eng. Soc., 2(38), 45-52, (2016)

13. A. Fraś, R. Przystaś, B. Tora, Ecological and economic aspects of the management of mining waste in TAURON Mining S.A., XVIII International Coal Preparation Congress, (Saint-Petersburg, Russia, Springer International Publishing, 2016.) ISBN: 978-3-319-40942-9 ; e-ISBN: 978-3-31940943-6 